\title{
Cars "Made in Europe"
}

\section{Doris Hanzl-Weiss}

The Vienna Institute for International Economic Studies, Austria, hanzl@wiiw.ac.at

\section{Robert Stehrer}

The Vienna Institute for International Economic Studies, Austria, stehrer@wiiw.ac.at

\section{CroEconSur}

Vol. 16

No. 1

April 2014

pp. $49-74$

Received: December 17, 2013

Accepted: March 13, 2014

Professional Article

doi:10.15179/ces.16.1.2

\section{Abstract}

The transport equipment industry is nowadays amongst the most important manufacturing industries, responsible for a large share of production, exports and R\&D in Central and Eastern European countries, particularly the Czech Republic, Slovakia and Hungary. This success is due to the fact that strong production linkages with Western European countries have been developed, particularly with Germany, spurred by large inflows of foreign direct investment and the arrival of large international car companies. Production processes in this industry are nowadays heavily internationally fragmented. We use the World Input-Output Database, which allows us to investigate the evolution of these production linkages across European countries and other major economies in the world in this industry. Considering the time period 1995-2011 and applying input-output indicators reveals changing patterns of domestic and international 
linkages, patterns of vertical specialization and direct and indirect value-added flows across countries in both the Western and Eastern European countries. By utilizing additional data we draw a more detailed picture of the evolution of these production linkages from which all countries have benefitted.

Keywords: input-output analysis, transport equipment sector, foreign direct investment, new member states

JEL classification: C67, L62

\section{Introduction ${ }^{1}$}

The transport equipment industry is nowadays amongst the most important manufacturing industries, responsible for a large share of production, exports and R\&D in the new member states (NMSs), particularly in the Czech Republic, Slovakia and Hungary. This success is due to the fact that strong production linkages with Western European countries have been developed, particularly with Germany, ${ }^{2}$ spurred by large inflows of foreign direct investment (FDI) and the arrival of large international car companies. It has turned this industry into a competitive and export-oriented one.

This paper will first look at the role of the transport equipment sector, in particular the automotive industry, in the NMSs. We will describe a subset of the NMSs including Bulgaria, the Czech Republic, Hungary, Poland, Romania, Slovakia and Slovenia. Thus the term NMSs refers here to these countries only. ${ }^{3}$ We will then show the importance of trade and the role of production linkages. Based on the World Input-Output Database (WIOD), indicators of production fragmentation in these countries and value-added trade flows will be presented.

1 The first draft of this paper was presented at the international conference "The Role of Europe's Industry in the 21st Century” organized by The Institute of Economics, Zagreb, November 21, 2013 in Zagreb, Croatia.

2 See, for example, IMF (2013).

3 Indeed, the automotive industry is not significant in the other NMSs (Baltic countries, Malta, Cyprus and Croatia). 
Finally, the paper will depict the history of foreign direct investment in the region which was one of the main driving forces behind the evolution of this sector in the region.

The change of the NACE classification system from NACE Rev. 1 to NACE Rev. 2 in 2008 has led to various problems and made long-term comparisons difficult. Thus, in the first sections we use data based on the new NACE Rev. 2 classification system in order to give an up-to-date overview, on a rather disaggregated level. The part of the paper using the WIOD is based on NACE Rev. 1 and uses a more aggregated level.

\section{The Role of the Automotive Industry in the NMSs}

The automotive industry, defined according to NACE Rev. 2 classification system as division 29 "motor vehicles, trailers and semi-trailers", is among the most important manufacturing sectors in all NMSs, except in Bulgaria. In the Czech Republic, Hungary, Romania and Slovakia it is in fact the largest manufacturing sector in terms of production value, with shares of 22, 19, 15 and even 29 percent, respectively. Likewise, in Poland and Slovenia it holds large shares of around 11 percent and is the second and third largest industry, respectively. In terms of production volume, the Czech Republic and Poland show the largest values (see Table 1). ${ }^{4}$ Due to its high capital intensity, the role of the automotive sector is less pronounced in employment terms, although it is still important. In the Czech Republic and Slovakia it is even the largest employer, with a share of 13 percent. In other countries the automotive industry also holds a prominent place - in Hungary it is the second largest employer behind the food industry, in Romania it is in third place, behind the food and clothing industry. In absolute terms, Poland and the Czech Republic have the highest numbers of employees (see Table 1).

4 For comparison, "other transport equipment" (division 30) is very small and ranges from 0.5 percent of manufacturing production in Hungary and Slovakia, 0.8 percent in Bulgaria, to 1.5 percent in the Czech Republic and Poland, and 2.3 percent in Romania. 
Table 1: Automotive Industry Overview (NACE Rev. 2, division 29), 2011

\begin{tabular}{|c|c|c|c|c|c|c|}
\hline & \multicolumn{2}{|c|}{ Production } & \multicolumn{2}{|c|}{ Employment ${ }^{l}$} & \multicolumn{2}{|c|}{ Foreign direct investment ${ }^{2}$} \\
\hline & $\begin{array}{c}\text { In millions } \\
\text { of EUR }\end{array}$ & $\begin{array}{c}\text { In } \% \text { of } \\
\text { manufacturing }\end{array}$ & Persons & $\begin{array}{c}\text { In } \% \text { of } \\
\text { manufacturing }\end{array}$ & \begin{tabular}{|c|} 
In millions \\
of EUR
\end{tabular} & $\begin{array}{c}\text { In \% of } \\
\text { manufacturing }\end{array}$ \\
\hline Bulgaria & 561.1 & 2.3 & 10,087 & 2.0 & n.a. & n.a \\
\hline $\begin{array}{l}\text { Czech } \\
\text { Republic }\end{array}$ & $31,647.8$ & 22.4 & 138,575 & 13.1 & 8,091 & 27.4 \\
\hline Hungary & $15,800.8$ & 18.6 & 65,022 & 10.3 & 3,382 & $19.6^{3}$ \\
\hline Poland & $26,669.1$ & 11.2 & 146,685 & 6.7 & 7,456 & 15.3 \\
\hline Romania & $9,046.0$ & 14.9 & 116,156 & 10.4 & 2,838 & 16.3 \\
\hline Slovakia & $16,435.8$ & 28.5 & 50,998 & 13.2 & 2,425 & 18.6 \\
\hline Slovenia & $2,598.5$ & 11.7 & 12,837 & 6.8 & 201 & 7.6 \\
\hline
\end{tabular}

Notes: ${ }^{1}$ Employment defined as number of employees, 2010; ${ }^{2}$ Inward FDI stock for category "manufacture of transport equipment"; ${ }^{3} 2010$

Sources: Eurostat (Structural Business Statistics), wiiw FDI Database.

What surprises most is the growing importance of the automotive industry in Romania. ${ }^{5}$ Looking at the detailed structure (at NACE three-digit level) more than 60 percent of production are car parts (29.3) in Romania, while in the Czech Republic, Poland and Hungary this share is about 50 percent and in Slovenia and Slovakia around 40 percent. Thus the production of motor vehicles (29.1) accounts for 60 percent in the latter two countries. ${ }^{6}$

In all NMSs the automotive industry was an important growth driver before the outbreak of the 2008 crisis. Production growth rates were high above growth rates for total manufacturing. The crisis hit the industry already in 2008, while the strongest production decline took place in 2009, with the automotive industry suffering more than total manufacturing (which was a general pattern of the trade slump and sectoral crisis effects). Growth recovered faster in the automotive industry in the following years but has been rather volatile ever since. Only in Romania no production decline occurred in 2009 and a continuous increase can be seen from the beginning of the 2000s (see Figure 1). Although

5 In 2007, the production share of Romanian automotive industry was 6 percent only (compare Hanzl-Weiss, 2012).

6 The remaining category, 29.2 "manufacture of bodies (coachwork) for motor vehicles; manufacture of trailers and semi-trailers", is rather small (between 1 and 3 percent) and thus not mentioned here. In Bulgaria, there is no production of motor vehicles, thus the automotive industry consists only of the production of car parts. 
not appearing in Figure 1, the Slovak automotive industry experienced the same development path as the industry in the other NMSs. High inflow of FDI in the 2000s expanded production capacities and the automotive industry became the growth driver in Slovakia as well. While also hit in 2009, the industry recovered fast and grew by almost 6 percent in 2012. All three main car companies in Slovakia introduced a third shift at the beginning of 2012 and the number of cars produced increased by 45 percent in that year, reaching about 927,000 cars (see Figure 2). With 171 automobiles produced per 1,000 inhabitants, Slovakia ranked first in the world (the Czech Republic ranked second). Slovenia's car industry still suffers from the crisis and car production figures declined in 2011 and 2012. In Poland, the once large producer FSO in Warsaw - orphaned by collapsing Daewoo of Korea - practically went out of business in the beginning of 2011, thus contributing to a sharp decline in the country's car production.

Figure 1: Automotive Industry (NACE Rev. 2, division 29): Volume Index of Production

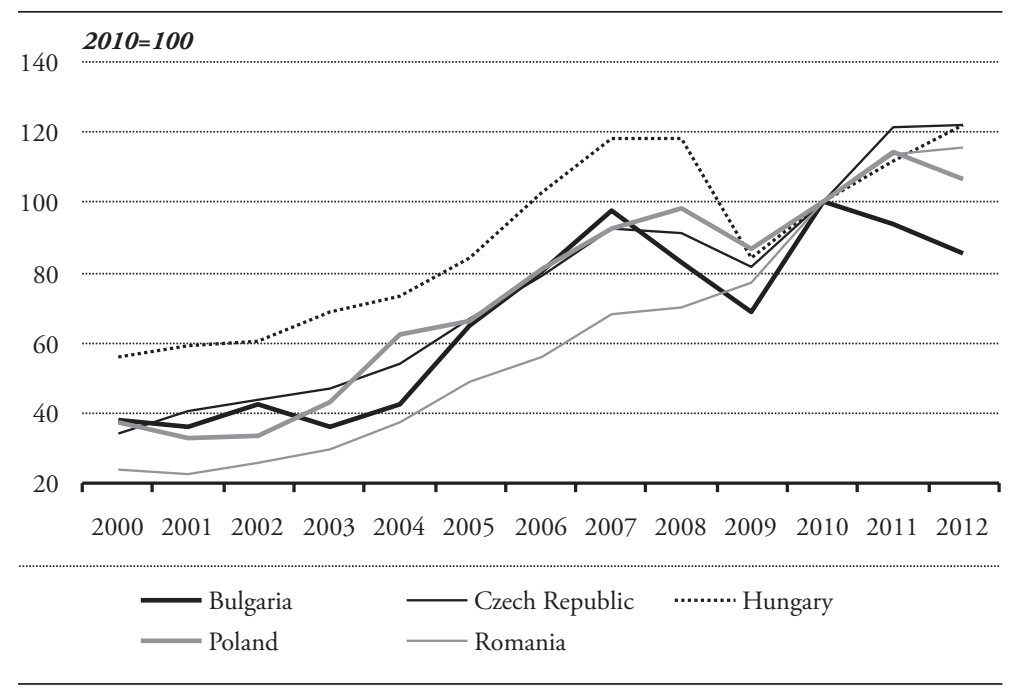

Note: No data available for Slovakia and Slovenia. Source: Eurostat (Structural Business Statistics). 
Figure 2: Passenger Car Production

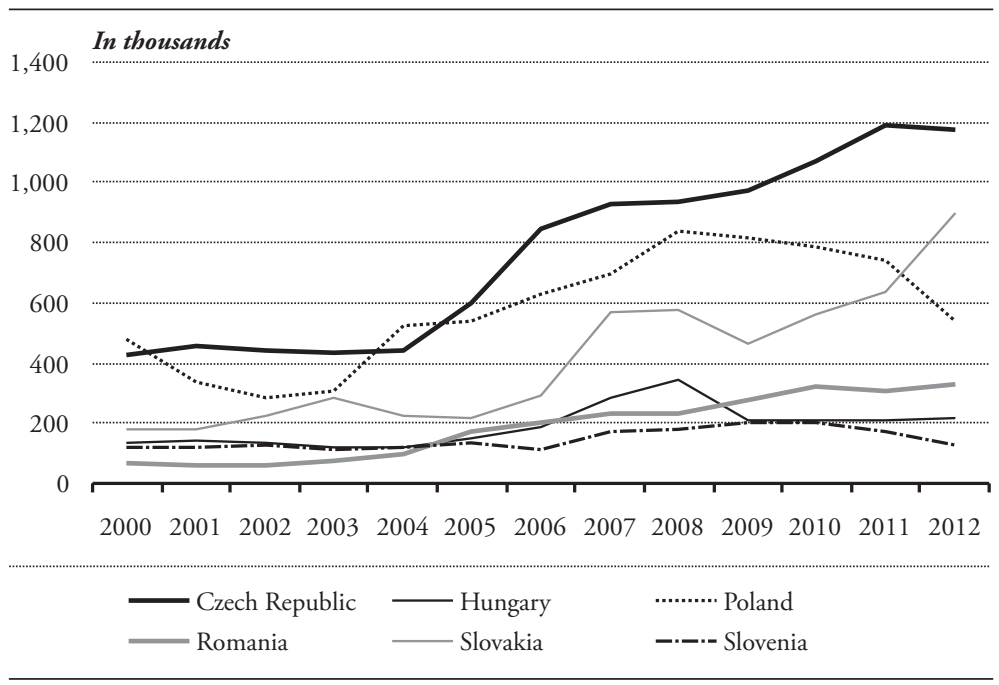

Source: International Organization of Motor Vehicle Manufacturers, http://www.oka.net.

\section{International Trade}

The automotive industry is a highly internationalized sector with external trade playing a major role. Foreign firms use their companies in the NMSs as export bases to the European market - for example, Kia in Slovakia sells less than 1 percent of its cars on the Slovak market itself. Thus the automotive industry is the largest export industry in manufacturing in all NMSs, except Hungary (here it is in second place, behind the computer and electronic industry). The automotive industry has an exceptionally large share of manufacturing exports in Slovakia, with 27 percent in 2012, while shares represent about 19 percent in the Czech Republic, Hungary and Romania. In Poland the share is somewhat smaller with 14 percent. In Bulgaria, exports of the automotive industry are less important and account for 3 percent of manufacturing exports.

Between 2000 and 2007 automotive exports expanded rapidly but were halted by the economic crisis in 2008. In 2009 automotive exports plunged in all 
NMSs except Romania and Bulgaria, where export growth continued. Exports recovered successfully in the Czech Republic and Slovakia and returned to their previous growth path. In Hungary and Poland automotive exports recovered as well but less dynamically: they reached the 2008 level only in 2012. In Slovenia automotive exports have not recovered yet, remaining 20 percent below their 2008 level (see Figure 3).

Figure 3: Automotive Exports (NACE Rev. 2, division 29)

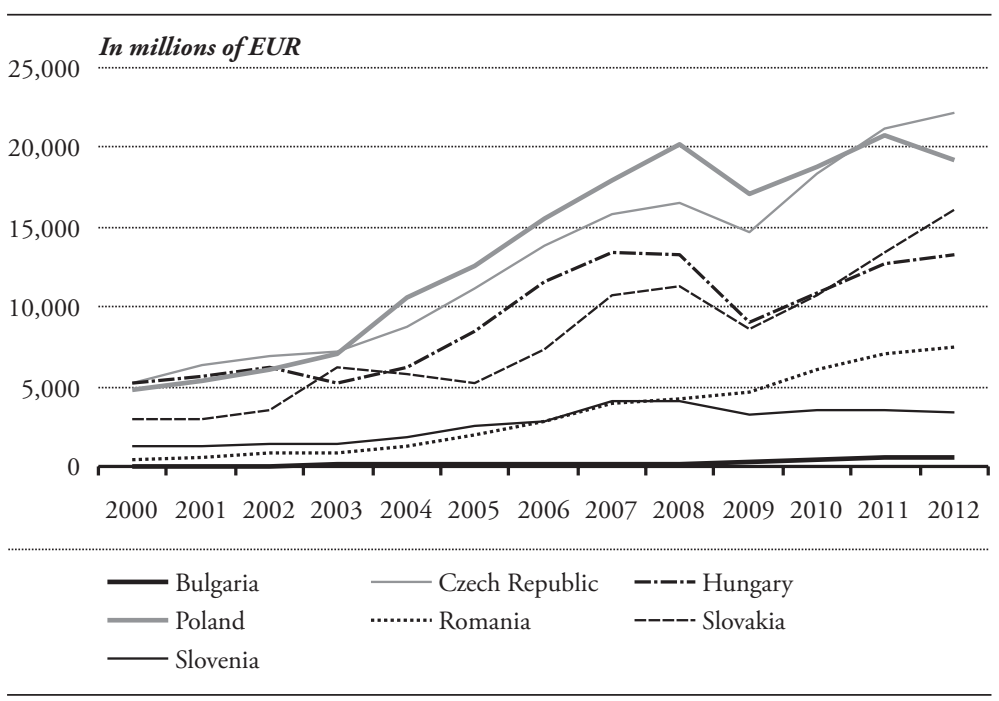

Source: Eurostat COMEXT.

The focus on different export markets might be one reason why export performance has varied across countries. While car registration plummeted on the European markets in the years after the crisis, potential growth markets were the US, China or Russia. Thus, automotive producers focusing only on the European market faced harder times than producers diversifying their exports to markets outside Europe. Overall, the majority of automotive exports in the NMSs go to the EU-15 countries, with shares of 70 percent. Exports to the NMS-10 are rather small and range between 11 and 14 percent. Exports outside 
the EU-27 account for less than 20 percent of total exports. Only in Romania and Slovakia this share amounts to about 30 percent, which might explain their relative better performance. In Slovenia this share is the lowest among all countries (16 percent, see Figure 4).

Figure 4: Structure of Automotive Exports (NACE Rev. 2, division 29) by Region, 2012

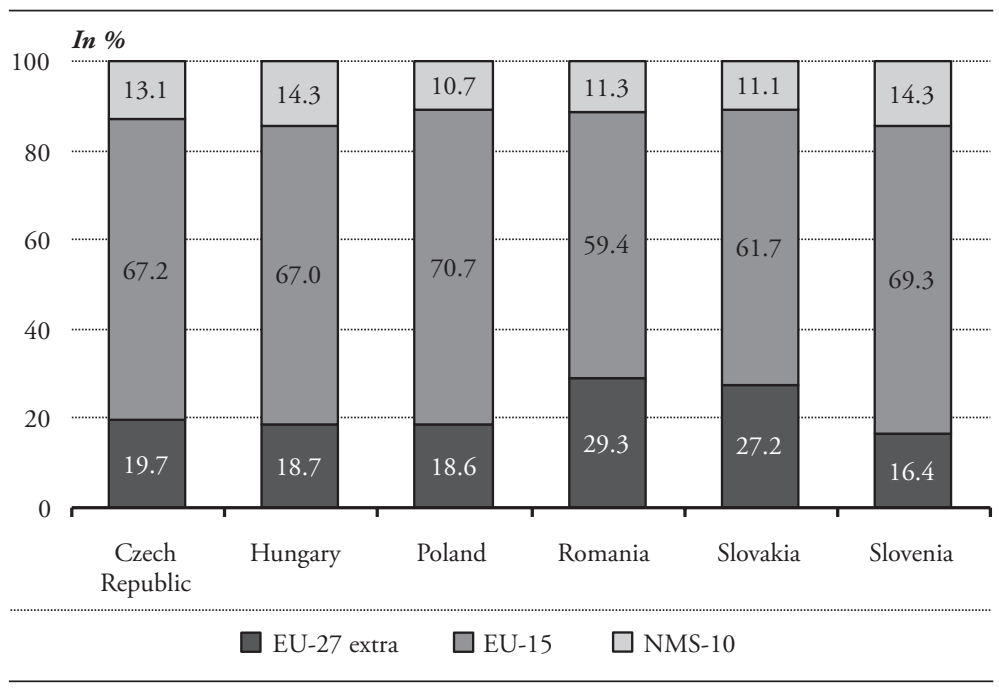

Source: Eurostat COMEXT.

\section{Production Linkages}

Studying exports in the automotive industry is not enough, as production fragmentation and thus imports do play a major role. In this respect it has to be mentioned that this fragmentation is a two-way process: on the one hand, intermediates are shipped to the NMSs, being used there for production purposes or assembly; on the other hand, these countries also serve as producers of intermediates shipped to the production lines of the other countries. Though each country or even each company is characterized by differences in these supply or value chains, insights about the importance of these flows and comparisons across countries can be drawn using the World Input-Output Database, which 
allows us to investigate the evolution of these production linkages across European countries and other major economies in the world. ${ }^{7}$ This database provides a consistent time series of global input-output tables for 40 countries together with a Rest-of-World category over the period 1995-2011. Countries are linked together via intermediate input flows across countries and industries and trade in final demand products. The WIOD is based on the NACE Rev. 1 classification system; divisions 34 ("manufacture of motor vehicles, trailer and semi-trailers") and 35 ("manufacture of other transport equipment") are grouped together, termed transport equipment sector. However, as we saw before, the "other transport equipment" sector is rather small. Looking at the time period 1995-2011 and applying input-output indicators reveals changing patterns of domestic and international linkages across industries and countries, patterns of vertical specialization and direct and indirect value-added flows across countries in both the Western and Eastern European countries.

At the outset, Figure 5a shows the share of value added in gross output of the transport equipment sector over the years 1995-2011. In 2011, this share ranged between 20 percent in Poland, 25 percent in the Czech Republic, Hungary and Slovenia to about 50 percent in Romania. This is due to the importance of intermediates in this industry, which in turn constituted 80 percent of gross output in Poland to 50 percent in Romania. ${ }^{8}$ A closer look at intermediates reveals that imports constituted about 60 percent of total intermediates in Hungary and Slovakia in 2011, about 55 percent in Slovenia and around 45 percent in the Czech Republic and Poland. For Romania and Bulgaria, this share was smaller and stood at 37 percent and 27 percent, respectively (see Figure 5b).

7 For details on this database see Dietzenbacher et al. (2013).

8 A comparison using Eurostat SBS data on the share of value added in production has shown somewhat different results: the value-added share for the automotive industry (29) is somewhat smaller at 20 percent and approximately the same in all countries, except for Slovakia (only 12 percent). Larger shares for the WIOD data might be due to the inclusion of "other transport equipment", which has normally larger value-added shares. 
Figure 5a: Share of Value Added in Gross Output, Transport Equipment (NACE Rev. 1, divisions 34\&35)

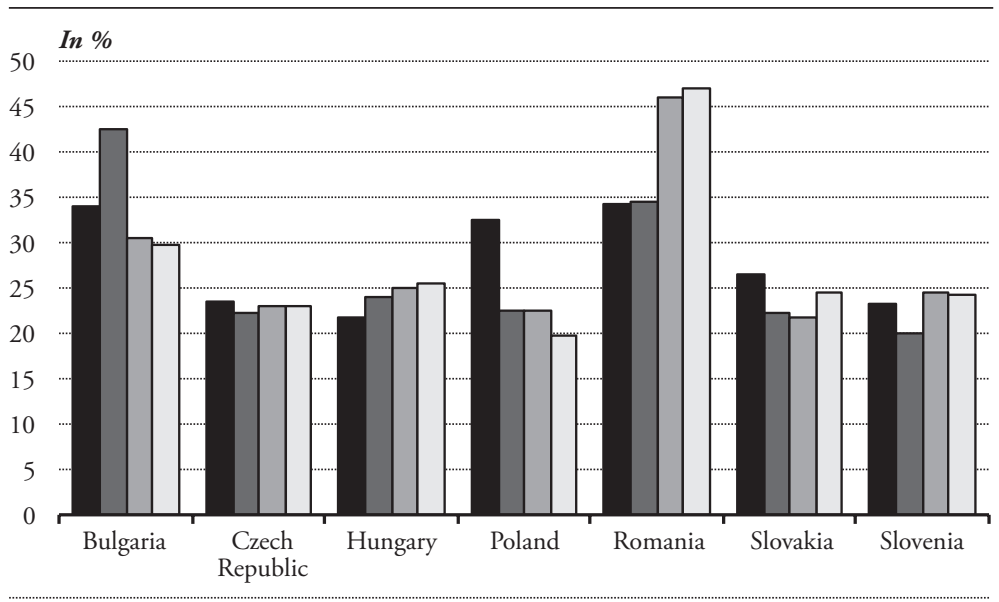

$1995 \square 2000 \quad \square 2007 \quad \square 2011$

Figure 5b: Share of Imports in Total Intermediates, Transport Equipment (NACE Rev. 1, divisions $34 \& 35$ )

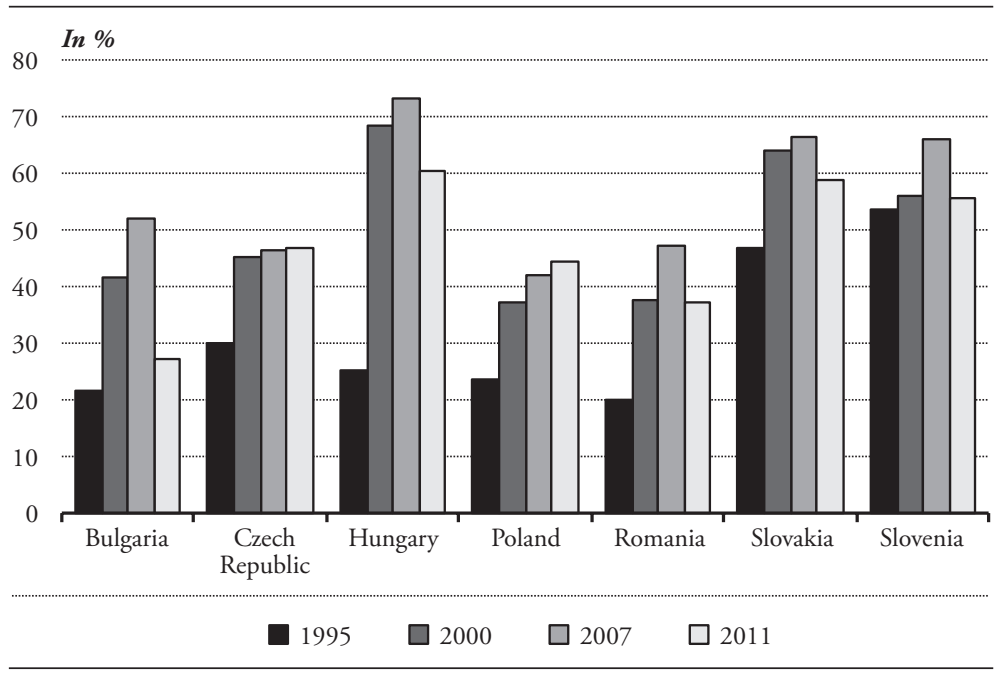

Source: WIOD. 
First insights can already be gained by considering the standard gross output multiplier. For this, one first has to calculate the Leontief inverse, i.e. (I-A) ${ }^{-1}$, where $I$ denotes the identity matrix and $A$ the coefficient matrix, i.e., the matrix of direct input coefficients. The column sum of the Leontief inverse then gives the output multiplier. The output multiplier for sector $i$ measures the total value of production in all sectors of the economy, necessary, directly and indirectly, to produce one monetary unit of production of the sector $i$ for final demand. In other words, the output multiplier measures the direct and indirect effects of an autonomous change of final demand in a particular industry on the total economy. It also can be interpreted as a "backward linkage", although more refined measures for backward linkages exist (see, e.g., Miller and Blair, 2009). When using the WIOD which also includes global linkages, the output multiplier in fact measures direct and indirect effects on the total world economy. This makes it possible to split up effects on the domestic economy and effects on the rest of the world.

Previous studies have shown that the transport equipment industry has in fact one of the largest output multipliers in the total economy (motor vehicles in particular, see European Commission, 2009). Figure 6a shows the total gross output multiplier for the transport equipment sector in the NMSs based on the WIOD. In 2011, it was particularly high for the Czech Republic and Slovakia, slightly below 3 for the other NMSs and somewhat lower for Romania (at 2.5, meaning that output of US\$2.5 is required for a dollar of new final demand'). In addition, this total gross output multiplier is split into its domestic and foreign output multipliers which are depicted as well (Figures $6 \mathrm{~b}$ and $6 \mathrm{c}$ ). The domestic output multiplier, measuring the impact on the country's own economy, has the largest value in Bulgaria, the foreign multiplier in Slovakia. What is especially interesting is the relative size of these two multipliers in 2011: the domestic multiplier was larger compared to the foreign multiplier in Bulgaria, Romania and

9 WIOD data are in millions of US\$. 
Poland. The difference, although existent, was smaller in the Czech Republic and Slovenia. In Hungary and Slovakia the foreign multiplier was slightly larger than the domestic one, signalling large backward linkages abroad. In most countries the domestic multiplier slightly declined over time while the foreign one strongly increased between 1995 and 2007 but declined over the crisis period. This strong increase over the pre-crisis period indicates the evolvement of supply chains and integration of these countries into them, partly driven by the patterns of foreign direct investment as outlined in more detail in the next section.

Figure 6a: Total Gross Output Multiplier for the Transport Equipment Sector (NACE Rev. 1, divisions $34 \& 35$ )

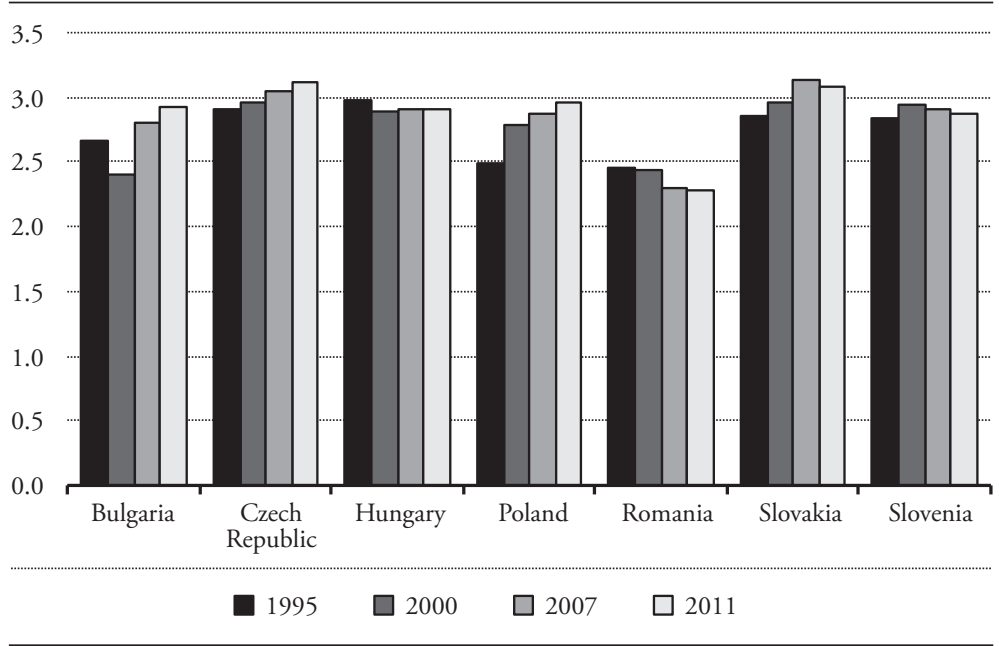


Figure 6b: Domestic Gross Output Multiplier for the Transport Equipment Sector (NACE Rev. 1, divisions 34\&35)

2.5

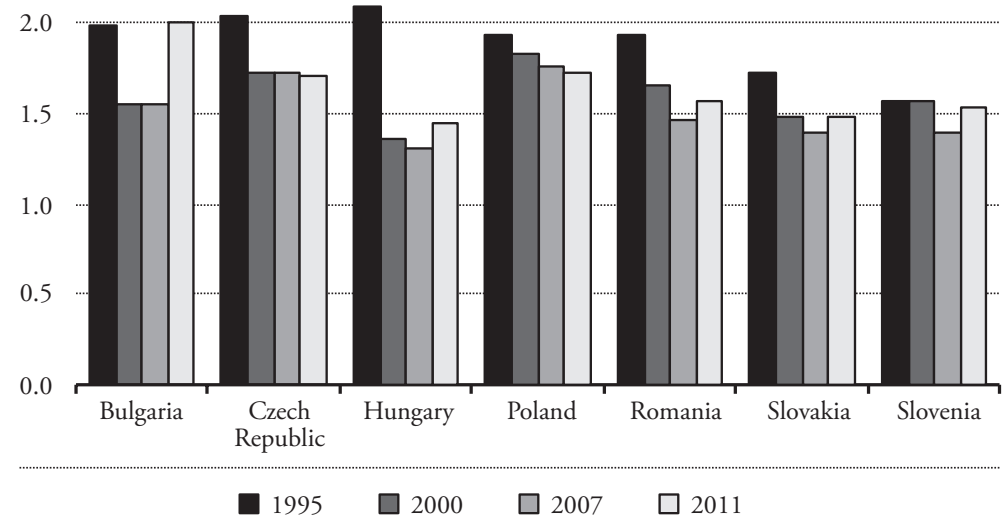

Figure 6c: Foreign Gross Output Multiplier for the Transport Equipment Sector (NACE Rev. 1, divisions 34\&35)

2.5

2.0

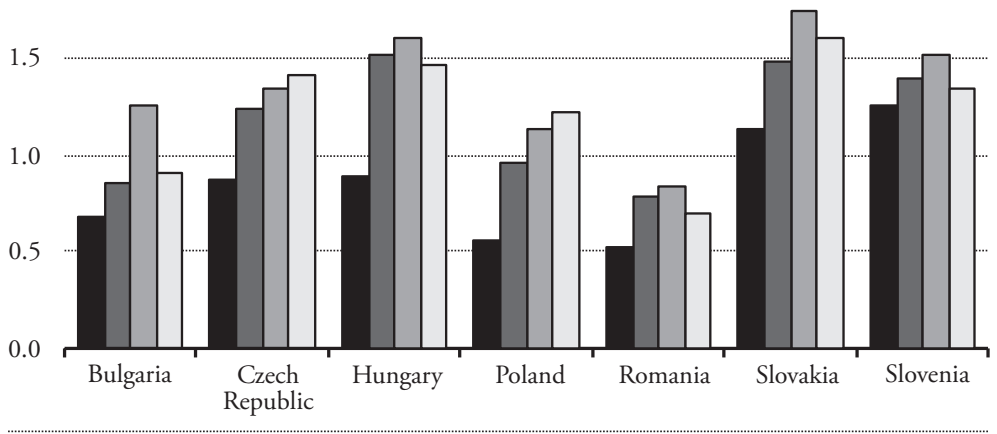

$1995 \square 2000 \square 2007 \square 2011$

Source: WIOD. 


\section{German Transport Equipment Supply Chain}

The integration of the NMS automotive industry into the Western European supply chains, especially the German one, has been of particular interest in recent studies (see, for example IMF, 2013). Thus, this section analyzes the linkages of the German transport equipment sector with the NMSs and selected European countries - Austria, France, Italy and the UK - and three non-European countries - China, Japan and the US.

Looking at the components of the German output multiplier first (i.e., the column elements of the Leontief inverse for Germany) shows the foreign sourcing structures of the German transport equipment sector (see Figure 7a). Among the NMSs, the Czech Republic and Poland have gained an increasingly important role in recent years, while traditionally sourcing from France, Italy or the US has been strong. However, in 2011, China took over this role and became the number one supplier for the German transport equipment industry.

Referring now to the components of other countries' output multipliers (i.e., the row elements of the Leontief inverse for Germany) shows the foreign supply structures of the German transport equipment sector (see Figure 7b). Here the NMSs play a decisive role and rank behind Austria, while the other Western European countries, China and the US are rather unimportant. Among the NMSs, however, different trends have emerged over time: for the main countries being supplied by Germany - the Czech Republic, Hungary and Slovakia, also Slovenia - a declining tendency is visible between 2000 and 2011. For the other countries - Bulgaria, Poland and Romania - there is an increasing tendency. This is possibly partly due to the foreign direct investment of other companies taking place in the 2000s (e.g., in Slovakia linkages with South Korea increased when Kia started production there) and the increasing importance of linkages with China. 
Figure 7: Transport Equipment (NACE Rev. 1, divisions 34\&35): Germany's Linkages with Selected Countries

\section{a) Backward Linkages}

0.15

0.10

0.05

0.00

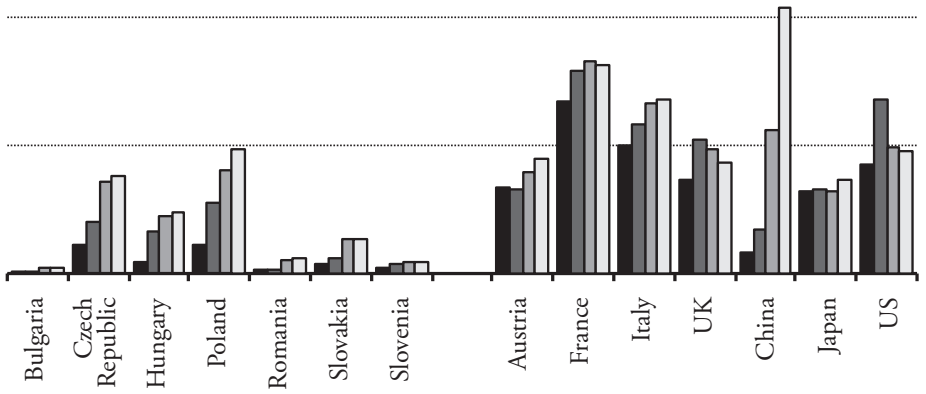

1995

2000

2007

2011

\section{b) Forward Linkages}

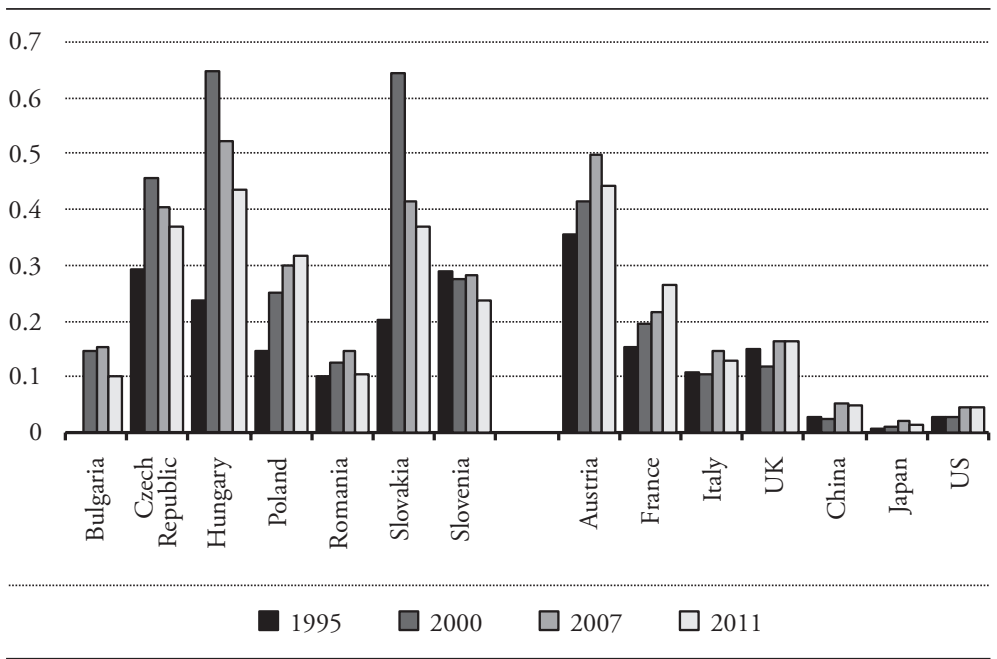

Source: WIOD. 
This increasing integration of production can also be looked at when considering the value added embodied in a country's exports. Specifically, the WIOD allows one to calculate the domestic and foreign value-added content of a country's exports with the latter being split into the various countries of origin. The foreign share of value added in a country's exports is commonly referred to as vertical specialization (see Foster-McGregor and Stehrer, 2013 for details).

Table 2 presents the share of the domestic and foreign value added embodied in a country's exports of the transport equipment industry (NACE Rev. 1, divisions $34 \& 35)$. The first striking fact is that domestic value-added share declined in all countries though picking up again after the crisis. The shares of the EU-14 (i.e., EU-15 without Germany), but particularly of Germany, strongly increased over the period considered, indicating the importance of inter-country value chains. Interestingly, these shares tended to decline in 2007 and after, with Rest-ofWorld and the other NMSs (EU-12*) gaining importance. The other big players - China, Japan and the US - play a relatively minor role.

Table 2: Foreign and Domestic Value-Added Content of Transport Equipment (NACE Rev. 1, divisions 34\&35) Exports in \% of Gross Exports

\begin{tabular}{|c|c|c|c|c|c|}
\hline & \multirow{2}{*}{1995} & \\
\hline & & & 2000 & 2007 & 2011 \\
\hline \multirow[t]{8}{*}{ Bulgaria } & Domestic & 68.74 & 63.17 & 48.94 & 62.46 \\
\hline & China & 0.14 & 0.39 & 1.74 & 1.63 \\
\hline & Germany & 4.23 & 6.17 & 6.42 & 4.18 \\
\hline & $\mathrm{EU}-12^{*}$ & 2.19 & 3.14 & 4.65 & 3.85 \\
\hline & EU-14 & 7.03 & 10.57 & 13.97 & 9.26 \\
\hline & Japan & 0.64 & 0.82 & 0.91 & 0.46 \\
\hline & Rest-of-World & 15.79 & 14.17 & 21.43 & 17.1 \\
\hline & US & 1.24 & 1.56 & 1.95 & 1.07 \\
\hline \multirow[t]{8}{*}{ Czech Republic } & Domestic & 61.29 & 48.71 & 47.95 & 46.91 \\
\hline & China & 0.22 & 0.63 & 2.05 & 3.55 \\
\hline & Germany & 13.44 & 19.31 & 16.5 & 14.67 \\
\hline & EU-12* & 5.19 & 3.93 & 6.97 & 6.82 \\
\hline & EU-14 & 11.1 & 15.67 & 15.03 & 13.45 \\
\hline & Japan & 0.88 & 1.28 & 1.49 & 1.47 \\
\hline & Rest-of-World & 5.56 & 6.86 & 8.23 & 10.81 \\
\hline & US & 2.31 & 3.62 & 1.79 & 2.32 \\
\hline
\end{tabular}




\begin{tabular}{|c|c|c|c|c|c|}
\hline \multirow[t]{8}{*}{ Hungary } & Domestic & 59.55 & 38.1 & 38.11 & 43.69 \\
\hline & China & 0.21 & 1.06 & 2.42 & 3.1 \\
\hline & Germany & 11.14 & 25.93 & 20.9 & 16.8 \\
\hline & EU-12* & 2.83 & 2.92 & 6.84 & 5.8 \\
\hline & EU-14 & 14.14 & 17.48 & 17.15 & 14.99 \\
\hline & Japan & 1.52 & 3.4 & 2.45 & 1.89 \\
\hline & Rest-of-World & 7.92 & 7.7 & 9.53 & 10.11 \\
\hline & US & 2.69 & 3.41 & 2.59 & 3.62 \\
\hline \multirow[t]{8}{*}{ Poland } & Domestic & 75.96 & 60.83 & 56.39 & 53.53 \\
\hline & China & 0.15 & 0.56 & 2.1 & 3.29 \\
\hline & Germany & 6.76 & 10.52 & 11.97 & 12.17 \\
\hline & EU-12* & 1.3 & 2.3 & 2.96 & 2.88 \\
\hline & EU-14 & 10.57 & 15.08 & 14.37 & 13.76 \\
\hline & Japan & 0.58 & 1.74 & 1.29 & 1.48 \\
\hline & Rest-of-World & 3.55 & 6.96 & 8.92 & 10.34 \\
\hline & US & 1.13 & 2.01 & 1.99 & 2.55 \\
\hline \multirow[t]{8}{*}{ Romania } & Domestic & 76.36 & 66.22 & 66.91 & 72.15 \\
\hline & China & 0.23 & 0.49 & 1.14 & 1.57 \\
\hline & Germany & 4.77 & 5.58 & 5.99 & 4.47 \\
\hline & EU-12* & 1.38 & 2.07 & 3.8 & 3.12 \\
\hline & EU-14 & 8.42 & 13.49 & 11.1 & 9.7 \\
\hline & Japan & 0.49 & 0.79 & 0.51 & 0.36 \\
\hline & Rest-of-World & 7.1 & 9.36 & 9.24 & 7.52 \\
\hline & US & 1.25 & 2 & 1.31 & 1.12 \\
\hline \multirow[t]{8}{*}{ Slovakia } & Domestic & 54.36 & 40.55 & 37.4 & 43.95 \\
\hline & China & 0.2 & 0.64 & 2.6 & 3.6 \\
\hline & Germany & 9.18 & 25.53 & 16.2 & 13.82 \\
\hline & EU-12* & 12.31 & 4.49 & 8.95 & 6.38 \\
\hline & EU-14 & 13.25 & 16.54 & 15.66 & 11.94 \\
\hline & Japan & 1.49 & 1.89 & 2.55 & 2.53 \\
\hline & Rest-of-World & 7.54 & 7.78 & 14.01 & 15.46 \\
\hline & US & 1.66 & 2.59 & 2.63 & 2.31 \\
\hline \multirow[t]{8}{*}{ Slovenia } & Domestic & 47.74 & 44.56 & 42.2 & 49.19 \\
\hline & China & 0.24 & 0.58 & 1.44 & 2.65 \\
\hline & Germany & 13.17 & 11.63 & 11.6 & 9.65 \\
\hline & EU-12* & 2.48 & 3.21 & 4.63 & 4.19 \\
\hline & EU-14 & 26.85 & 28.52 & 24.4 & 19.05 \\
\hline & Japan & 1.47 & 1.47 & 1.11 & 1.08 \\
\hline & Rest-of-World & 6.21 & 7.74 & 12.49 & 12.09 \\
\hline & US & 1.86 & 2.28 & 2.13 & 2.09 \\
\hline
\end{tabular}

Note: EU-14 is EU-15 without Germany; EU-12* means EU-12 without the respective country.

Sources: WIOD; authors' calculations. 
Oppositely, Germany and Austria also increasingly use inputs from the NMSs which is shown in Table 3. These shares of EU-12 value added embodied in Germany's and Austria's exports are generally increasing, but are relatively low at about 4.5 percent in 2011. These numbers have to be compared with the share of Germany in the NMSs' exports which goes up to about 30 percent for some countries.

Table 3: Foreign and Domestic Value-Added Content of Transport Equipment (NACE Rev. 1, divisions 34\&35) Exports in \% of Gross Exports

\begin{tabular}{|c|c|c|c|c|c|}
\hline & \multirow{2}{*}{1995} & & \\
\hline & & & 2000 & 2007 & 2011 \\
\hline \multirow[t]{8}{*}{ Austria } & Domestic & 61.4 & 55.2 & 48.2 & 49.9 \\
\hline & China & 0.2 & 0.5 & 1.6 & 2.5 \\
\hline & Germany & 16.3 & 17.0 & 19.7 & 17.1 \\
\hline & EU-12 & 1.7 & 2.8 & 4.7 & 4.6 \\
\hline & EU-15* & 11.2 & 12.8 & 13.4 & 12.7 \\
\hline & Japan & 1.6 & 2.0 & 1.7 & 1.8 \\
\hline & Rest-of-World & 5.1 & 6.4 & 8.0 & 9.0 \\
\hline & US & 2.5 & 3.4 & 2.8 & 2.5 \\
\hline \multirow[t]{7}{*}{ Germany } & Domestic & 79.0 & 72.5 & 68.2 & 65.6 \\
\hline & China & 0.3 & 0.6 & 1.5 & 2.9 \\
\hline & EU-12 & 1.3 & 2.6 & 4.1 & 4.6 \\
\hline & EU-15* & 12.1 & 13.7 & 14.5 & 14.1 \\
\hline & Japan & 1.3 & 1.3 & 1.2 & 1.3 \\
\hline & Rest-of-World & 4.2 & 6.3 & 8.2 & 9.4 \\
\hline & US & 1.9 & 3.0 & 2.2 & 2.3 \\
\hline
\end{tabular}

Note: EU-15* means EU-15 without the respective country.

Sources: WIOD; authors' calculations.

These differences in magnitudes are partly driven by size differences across countries. It is therefore interesting to look at that from a different perspective. Table 4 shows an indicator comprising the share of a country's value added in another country's exports in percent of its GDP. For example, German exports embody to a certain extent value added from Slovakia which is expressed as a share of the latter country's GDP. The total GDP is used as the value added embodied in Germany's exports is not only value added created in the respective 
sector, i.e., the transport equipment industry, but in the whole economy due to inter-industry linkages. ${ }^{10}$

Table 4: Value Added Embodied in Germany's Transport Equipment Exports in \% of GDP

\begin{tabular}{l|c|c|c|c}
\cline { 2 - 4 } & $\mathbf{1 9 9 5}$ & $\mathbf{2 0 0 0}$ & $\mathbf{2 0 0 7}$ & $\mathbf{2 0 1 1}$ \\
\cline { 2 - 4 } & 3.56 & 5.14 & 6.49 & 5.87 \\
Germany & 0.04 & 0.06 & 0.13 & 0.12 \\
China & 0.42 & 0.88 & 1.10 & 1.09 \\
\hline EU-12 & 0.22 & 0.30 & 0.37 & 0.36 \\
\hline EU-15* & 0.03 & 0.04 & 0.08 & 0.07 \\
\hline Japan & 0.06 & 0.11 & 0.15 & 0.12 \\
\hline Rest-of-World & 0.03 & 0.04 & 0.05 & 0.05 \\
\hline US & & & \\
\hline
\end{tabular}

Note: EU-15* means EU-15 without Germany.

Sources: WIOD; authors' calculations.

For example, Germany's domestic value added embodied in its exports of the transport equipment industry (NACE Rev. 1, divisions 34\&35) accounts for almost 6 percent of its GDP in 2011, increasing from about 3.5 percent in 1995. German exports also embody value added from the other countries. With respect to the EU-12, the EU-12 value added embodied in Germany's transport equipment industry exports accounts for about 1.1 percent of these countries' GDP compared to 0.4 percent in 1995 . Figure 8 presents the evolutions of these dependencies for the NMSs selected for this study. The highest shares are found for the Czech Republic, Hungary and Slovakia, where value added embodied in Germany's transport equipment exports accounts for about 1.8 percent of GDP (with a stronger decline in the case of Slovakia to 1.4 percent in 2011). For the other countries these shares go up to about 1 percent in the case of Slovenia and Poland. The lowest shares are found for Romania and Bulgaria with about 0.5 percent. In all cases these shares have been increasing and particularly strongly so for the Czech Republic, Hungary, Poland, Slovakia and Slovenia.

10 Using the foreign and domestic value added embodied in a country's exports can be seen as an approximation as one would have to take account of value added returning to the country of origin which is, however, relatively small (see Stehrer, 2013, for an assessment at the bilateral level). 
Figure 8: Value Added Embodied in Germany's Transport Equipment Exports

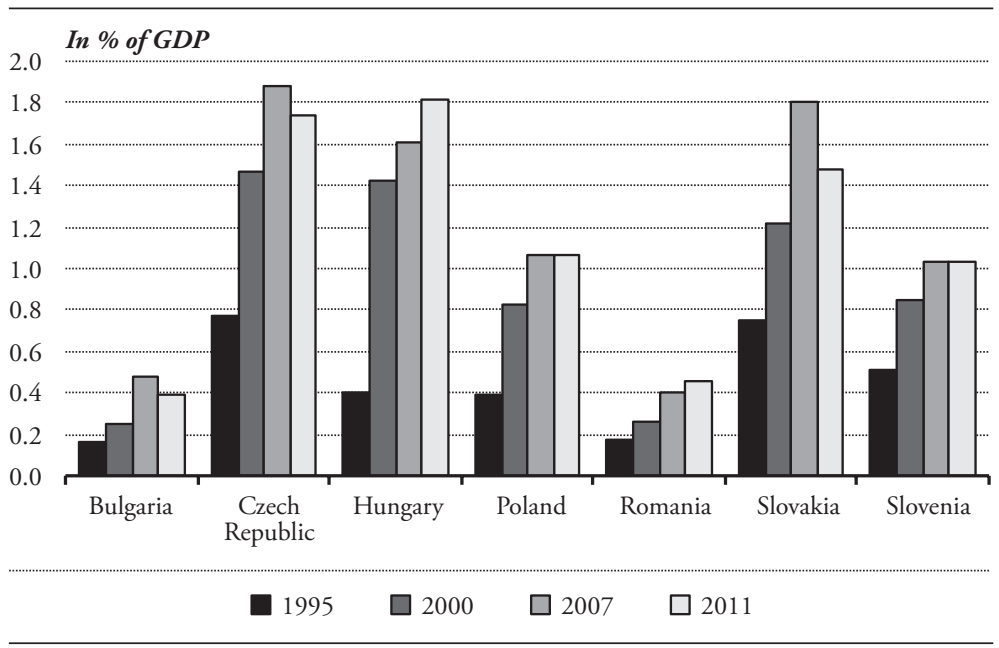

Sources: WIOD; authors' calculations.

\section{The Role of Foreign Direct Investment}

Foreign direct investments have played an important role in the evolution of this industry. Since the collapse of communism in 1989, the inflow of foreign direct investment has shaped the automotive industry in the new member states and has transformed it into a competitive, export-oriented industry. Historical ties have played a role in this process, e.g., in the case of Renault's investment in Slovenia, or Fiat's in Poland, while the accession to the European Union in 2004/2007 was an important motive for overseas companies (from South Korea, Japan and recently China).

In Slovenia, the French car company Renault had historical ties and created a joint venture called Revoz already in 1988. In the Czech Republic and Slovakia, the first foreign company to arrive was Volkswagen in 1991 (still Czechoslovakia then). Volkswagen formed joint ventures with already existing companies which became Škoda Auto and VW Bratislava, respectively (Hanzl, 1999). However, foreign investment climate was unfavorable in these first years in the 
Czech Republic and Slovakia, unlike Hungary. Hungary opened its economy for foreign investors soon after 1989 and automotive investors arrived quickly: GM/Opel (car assembly, engines) and Suzuki came in 1992, Audi (engines) in 1993 - all by means of greenfield investments - and suppliers soon followed. In Poland, large foreign companies bought existing firms, e.g., Fiat bought FSM in 1992, Daewoo FSO in 1995, or established assembly plants, e.g., General Motors. In Romania, Daewoo from South Korea formed a joint venture in 1994, while Renault acquired 51 percent of Automobile Dacia Piteşti in 1999 with whom it had a long-time license agreement (see Hanzl, 1999).

After this first wave of privatization and investments in the 1990s, the automotive industry continued to attract FDI in the 2000s as well: choosing Slovakia, PSA Peugeot Citröen announced to build a greenfield plant in 2003; Kia Motors in 2004. Production started in both plants in 2006. Locating in the Czech Republic, Toyota Peugeot Citröen made an investment decision in 2002 and started production in early 2005. Hyundai announced to invest in the Czech Republic in 2005, following its sister company Kia, and the plant was completed in 2008. Finally, in Hungary, Mercedes decided to build an assembly plant in Kecskemét in 2008. Production began in March 2012. Only in Romania, the investment path was not that smooth: due to the collapse of the main parent company Daewoo, the Romanian company experienced troubles and the state took over shares from the Automobile Craiova company in 2006. Stakes in the company were sold step-by-step to Ford between 2007 and 2009. In Bulgaria, the Chinese company Great Wall opened a car factory in February 2012, together with Bulgarian company Litex.

Today, inward FDI stock for the whole transport equipment industry (including other transport equipment as well, but serves as a good proxy for the automotive industry) ranges between EUR 3 billion in Hungary, Romania and Slovakia and EUR 8 billion in the Czech Republic and Poland. Only in Slovenia the amount is lower (see Table 1). Again, the transport equipment industry holds an important position within manufacturing, being the largest recipient of FDI 
in all countries, except in Poland (behind the food industry) and Slovenia (on a lower rank, here the pharmaceutical industry is the major recipient).

Table 5 shows the largest automotive companies in the NMSs ranked by revenue. Škoda Auto is in fact the third largest company in the NMS region and the largest automotive company. Volkswagen Slovakia overtook AUDI Hungary in 2012 and became the second largest automotive company. Kia Motors Slovakia overtook Fiat in 2012 and became the fourth largest company; Automobile Dacia in Romania ranked sixth. Table 6 presents another ranking of automotive companies in 2011. This list contains thirty automotive companies, displaying the importance of car parts manufacturers in particular. Poland shows the largest number of companies (9), followed by the Czech Republic and Hungary (both 6) and Slovakia (5). In Romania and Slovenia only 2 automotive companies made it on the list.

Table 5: The Main Automotive Companies, 2012

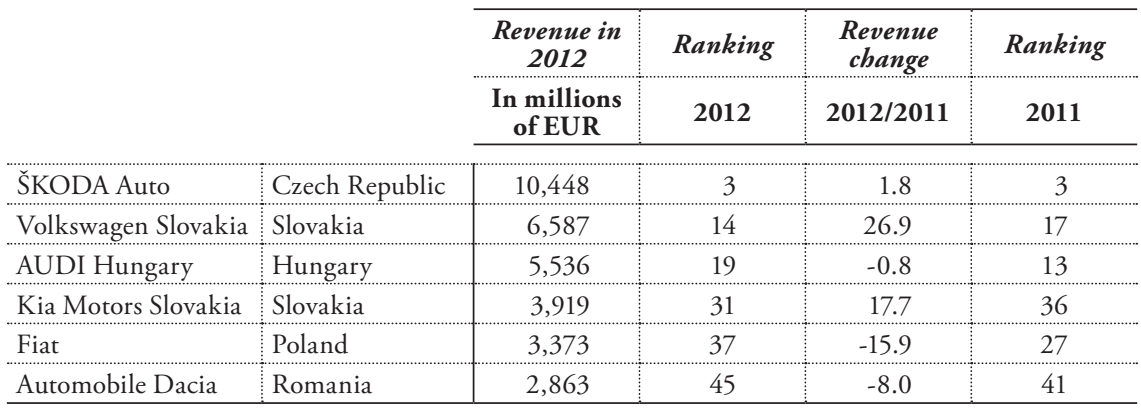

Source: Deloitte (2013). 


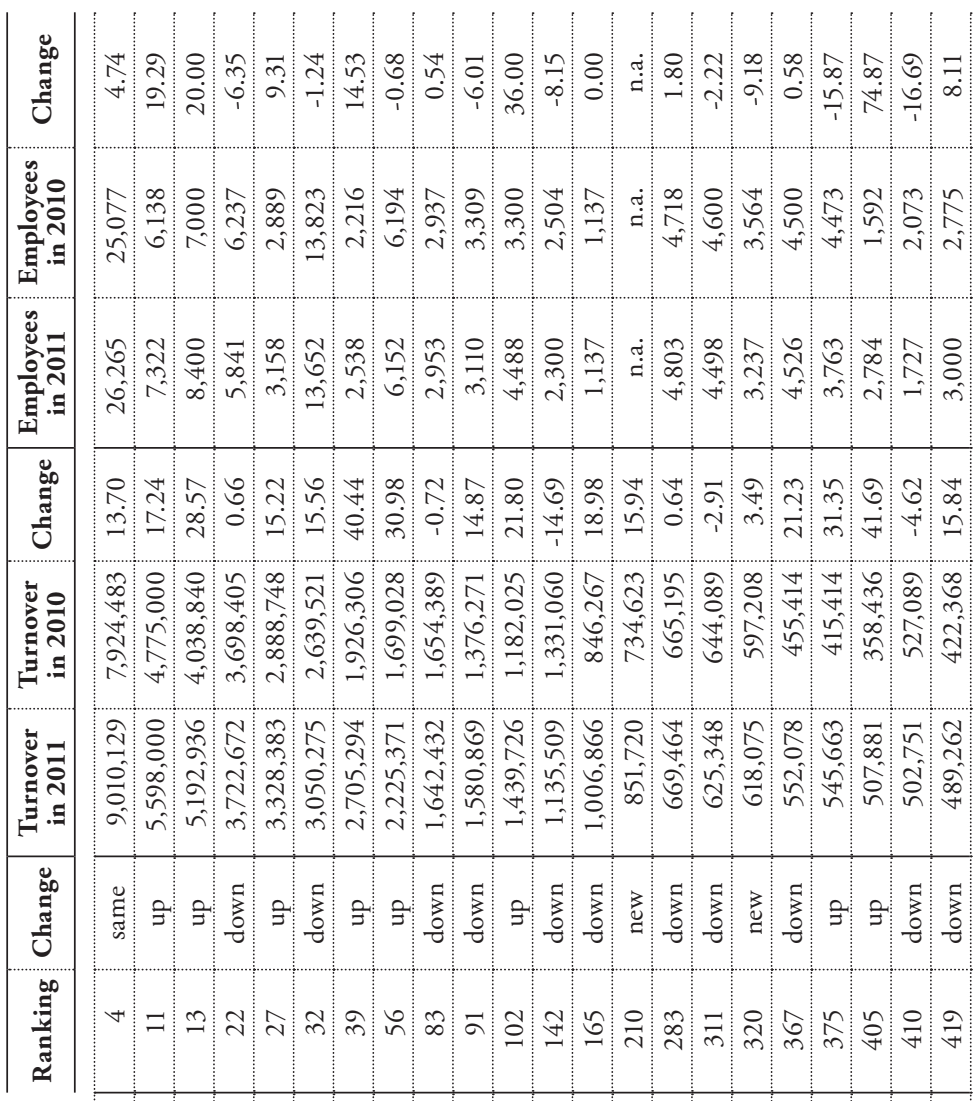




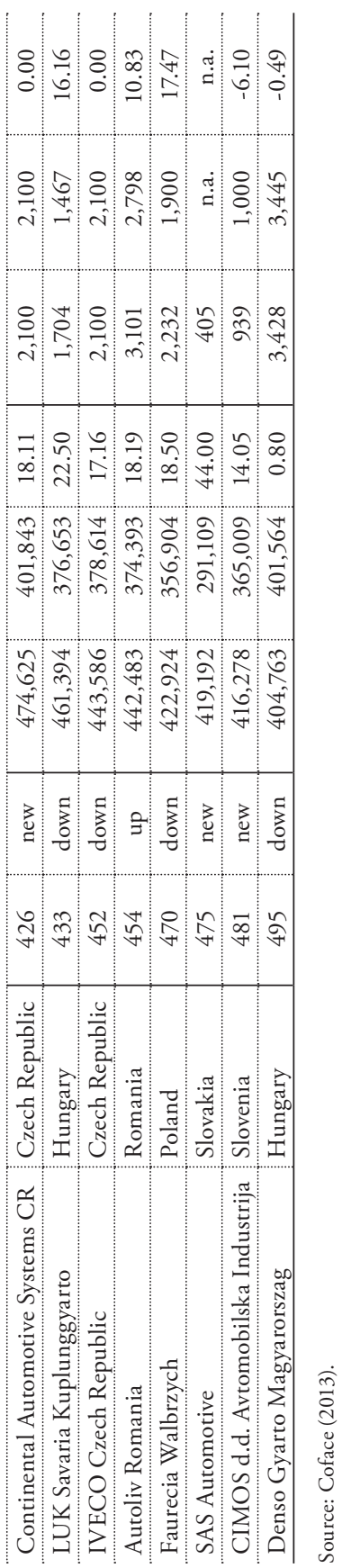




\section{Conclusions}

In the last twenty years, the automotive industry in the NMSs has become an important, export-oriented industry, mainly as a result of a massive inflow of foreign direct investment. It is important to acknowledge that this has been a long-term process, often based on historical ties which had already been built before the collapse of communism. These foreign firms use their companies in the NMSs as export bases to the European market. Integration with Western European countries is thus strong, while ties among the NMSs themselves are less developed. More than 80 percent of automotive exports go to countries of the European Union, of which 70 percent to the EU-15 countries. However, as production fragmentation plays a major role in this industry, imports are important too. Indeed, the NMSs are highly dependent on imports. In the most integrated countries (the Czech Republic, Hungary, Slovakia and Slovenia) foreign value added embodied in car exports is above 50 percent. Germany plays a major role in this process, being a major supplier to the NMSs. Integration with Germany has been strong especially for Hungary, the Czech Republic and Slovakia, but also for Poland and Slovenia. It is lower for Bulgaria and Romania, which are generally less integrated into Western European supply chains.

\section{Literature}

Coface, 2013, “Coface CEE Top 500: 2012”, http://www.coface.at/CofacePortal/ AT/de_DE/pages/home/infocorner/Top500 (accessed September 26, 2013).

Deloitte, 2013, “Top 500 Central Europe, 2013”, https://www.deloitte.com/ en_GX/global/insights/deloitte-research/strategy-cross-industry-research/ af9c388a90ffd110VgnVCM100000ba42f00aRCRD.htm\#.UkwYtFPHXXQ (accessed September 4, 2013). 
Dietzenbacher, Eric, Bart Los, Robert Stehrer, Marcel Timmer and Gaaitzen de Vries, 2013, "The Construction of World Input-Output Database in the WIOD Project", Economic Systems Research, 25(1), pp. 71-98. http://dx.doi.org/10.1080/ 09535314.2012.761180

European Commission, 2009, EU industrial structure 2009: Performance and competitiveness, Luxembourg: Enterprise and Industry DG.

Foster-McGregor, Neil and Robert Stehrer, 2013, "Value Added Content of Trade: A Comprehensive Approach", Economics Letters, 120(2), pp. 354-357. http://dx.doi.org/10.1016/j.econlet.2013.05.003

Hanzl, Doris, 1999, "Development and Prospects of the Transport Equipment Sector in Central and Eastern European Countries", wiiw Industry Studies, No. 1999/4, December, Vienna: wiiw.

Hanzl-Weiss, Doris, 2012, "Internationalisation of R\&D in the automotive sector of the Czech Republic, Hungary, Slovakia and Romania”, Internationalization of business investments in R\&D and analysis of their economic impact, Luxembourg: European Commission Directorate General for Research and Innovation.

IMF, 2013, "German-Central European Supply Chain-Cluster Report", IMF Country Report, No. 13/263, August, Washington, DC: IMF.

Miller, Ronald E. and Peter D. Blair, 2009, Input-Output Analysis: Foundations and Extensions, Second Edition, New York, NY: Cambridge University Press. http://dx.doi.org/10.1017/CBO9780511626982

Stehrer, Robert, 2013, "Accounting Relations in Bilateral Value Added Trade", wiiw Working Paper, No. 101, May, Vienna: wiiw Working Papers. 